\title{
DIAGNOSTIC CHALLENGES WITH INTRAORAL MYELOID SARCOMA: REPORT OF TWO CASES \& REVIEW OF WORLD LITERATURE
}

\author{
P. Kumar ${ }^{1, *}$, H. Singh ${ }^{1}$, N. Khurana ${ }^{2}$, A.B. Urs ${ }^{1}$, J. Augustine ${ }^{1}$, R. Tomar ${ }^{2}$ \\ ${ }^{1}$ Department of Oral Pathology, Maulana Azad Institute of Dental Sciences, BSZ Marg, New Delhi 110002, India \\ ${ }^{2}$ Department of Pathology, Maulana Azad Medical College, BSZ Marg, New Delhi 110002, India
}

Background: Myeloid sarcomas (MS) are rare extramedullary tumors composed of blasts of myeloid lineage that either precede, follow or present concomitantly with acute myeloid leukaemia (AML) or myeloproliferative neoplasms. The diagnosis of MS is especially challenging in patients without an antecedent history of leukemia. Methods: We present 2 cases of intraoral MS that presented as de novo lesions. A detailed review of cases of intraoral MS that either preceded or presented along with leukemia has been done with emphasis on diagnostic criteria used. Results: Two male patients aged 28 and 5 years presented with MS with one patient presenting with concomitant AML. A combination of morphological and immunohistochemical methods was used for diagnosis. A thorough review of world literature revealed 44 cases of intraoral MS that presented as de novo lesions. Conclusion: Intraoral MS is a rare tumor with poor prognosis. It may be diagnostically challenging due to its protean clinical manifestations and histological overlap with other tumors. Key Words: myeloid sarcoma, leukemia, granulocytes, immunohistochemical method.

Myeloid sarcoma (MS) is a pathologic diagnosis for an extramedullary proliferation of blasts of one or more myeloid lineages that leads to effacement of the tissue architecture in which it is found [1]. Originally called chloromas due to the greenish color on gross examination attributed to production of myeloperoxidase, it has subsequently undergone numerous changes in nomenclature including granulocytic tumor, extramedullary myeloid tumor and myeloblastoma. This change in nomenclature reflects the various facets of the historical evolution of this tumor corresponding with molecular and cytogenetic understanding of the neoplasm.

MS is usually observed in a setting of acute myeloid leukemia (AML), myeloproliferative neoplasms and mixed myelodysplastic/myeloproliferative neoplasms (50\%). Appearance of MS in an AML patient in remission is an indication of relapse. Rarely MS has presented after allogenic stem cell transplantation [2, 3]. $15-35 \%$ of $\mathrm{MS}$ cases are detected concomitantly with AML, however, it is the remaining $25-27 \%$ that precede AML that create a diagnostic dilemma.

Intraoral MS is an exceedingly rare lesion with only about 75 cases reported since its first description in 1811. Almost all intraoral sites can be involved including the jaws, gingiva, hard and soft plate, tonsils, maxillary sinus, tongue and lips. Here we present two cases of intraoral MS along with review of world literature. Emphasis has been placed on the diagnostic criteria used by various authors. We also present differential diagnosis, approaches to diagnosis and pitfalls in diagnosing MS when it precedes or is diagnosed with AML based on review of world literature.

\footnotetext{
Submitted: November 18, 2016.

*Correspondence: E-mail: drpri_kumar@yahoo.com Abbreviations used: AML - acute myeloid leukemia; MPO - myeleoperoxidase; MS - myeloid sarcoma.
}

\section{CASE REPORTS}

Case I

A 28 year old monoplegic male presented with a progressively enlarging swelling on left side of face, since 5-6 months (Fig. 1, a). He had undergone extraction of 36.2 months ago due to mobility. Physical examination revealed ill defined bony hard swelling extending from the left ala tragus line up to lower border of mandible with involvement of ramus and angle of mandible. Intraorally, expansion on buccal aspect of \#34 to \#37 and healed extraction socket of \#36 were noted. Orthopantomogram showed ill defined mixed radiolucent and radiopaque lesion with respect to left angle of mandible extending up to the ramus of mandible (Fig. 1, b). Laboratory studies including complete blood count and serum chemistry were within normal range.

Incisional biopsy was performed via intraoral approach. Histopathological examination revealed a diffuse infiltration of large atypical cells with vesicular nuclei with predominance of crushed nuclei. The atypical cells were seen infiltrating in between and splaying the muscle fibers (Fig. 1, c). A basic immunohistochemical panel consisting of pancytokeratin, vimentin, S100, CD45, and desmin was performed. The tumor cells were positive for CD45 (Fig. 1, d) and a presumptive diagnosis of non-Hodgkin's lymphoma was made. However, the cells were negative for CD3 and CD20. The H\&E slides were re-examined and a population of large cells containing eosinophilic granules (Fig. 1, e) was seen intermingling with the tumor cells with areas of degranulation.

Based on all previous investigations and histopathological findings, anti-myeleoperoxidase antibody (anti-MPO) staining (Fig. 1,f) was performed which showed strong diffuse positivity. Bone marrow biopsy was within normal limits. A diagnosis of MS in the absence of AML was thus made. 
Patient underwent induction chemotherapy with cytarabine and idarubucin with lesion regression. He has remained in remission for 14 months after diagnosis with normal blood counts.

\section{Case II}

A 5 year old male child was referred to our Centre by a private dentist with rapidly progressing mildly tender swelling in left posterior mandibular region (Fig. 2, a), since last 10 days. History of trauma was elicited 25 days prior to commencement of swelling and there was no history of any systemic disease. Examination revealed a well defined bony hard swelling with expansion of buccal and lingual cortices. The left deciduous molars were mobile and displaced due to the swelling (Fig. 2, b). A large area of ulceration was noted on the linguo-occlusal aspect. Orthopantomogram showed an ill defined mixed radiolucent radiopaque lesion causing resorption of molar roots
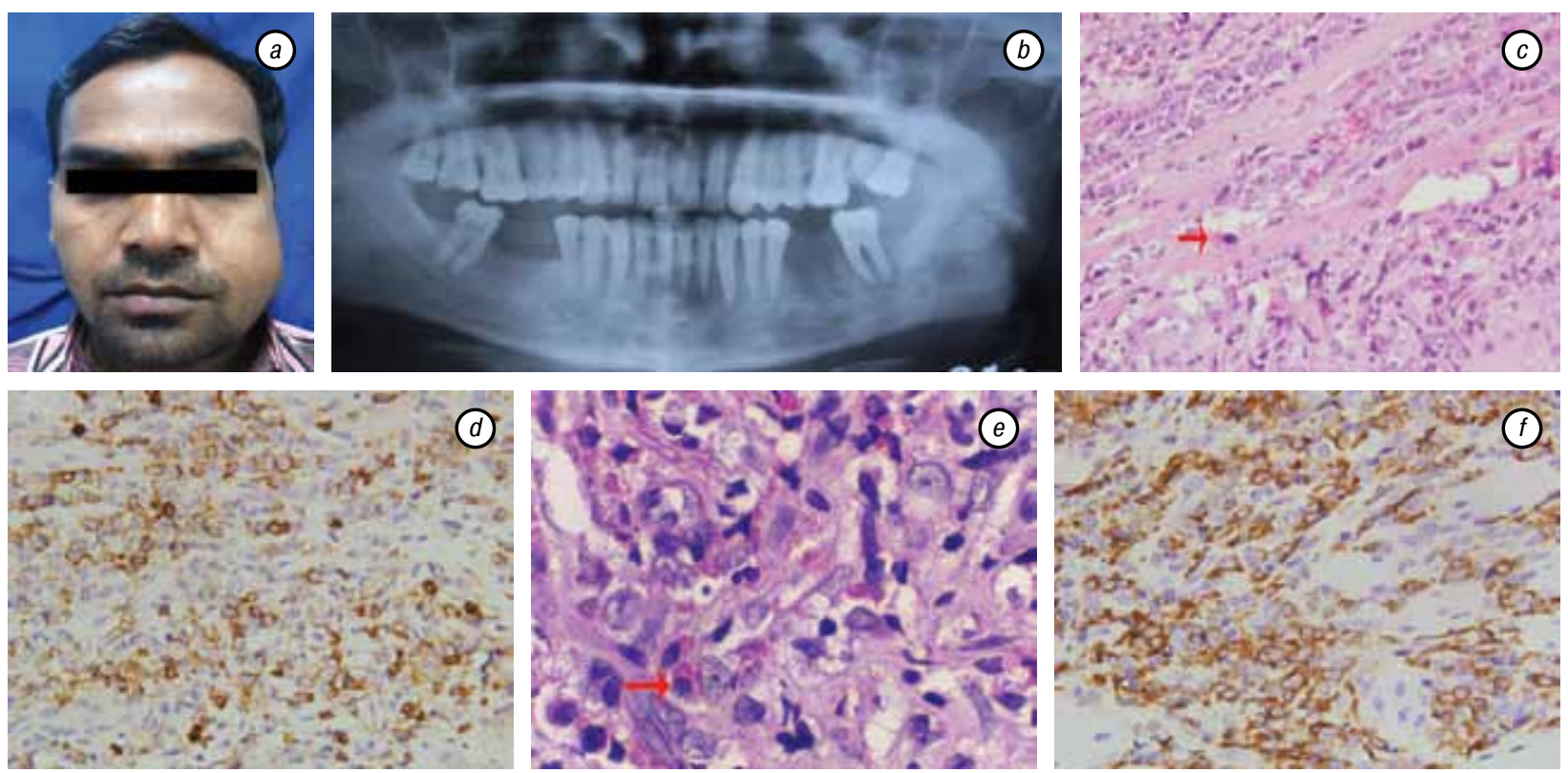

Fig. 1. Clinical, radiographic, histological and immunohistochemical findings of Case \#1: a - extra oral photograph showing diffuse swelling over left mandible; $b$ - orthopantogram showing poorly defined mixed radiolucent-radio opaque mottled lesion with partially healed socket of \#36; $c$ - microphotograph showing tumor cells invading in between and splaying muscle fibers (H \& E, $\times 100$ ); $d$ - microphotograph showing diffuse positivity for CD45; $e-$ higher magnification showing granular eosinophilic myelocytes (arrow) intermingling with immature tumor cells (H \& E, $\times 1000) ; f$ - microphotograph showing strong positivity for MPO
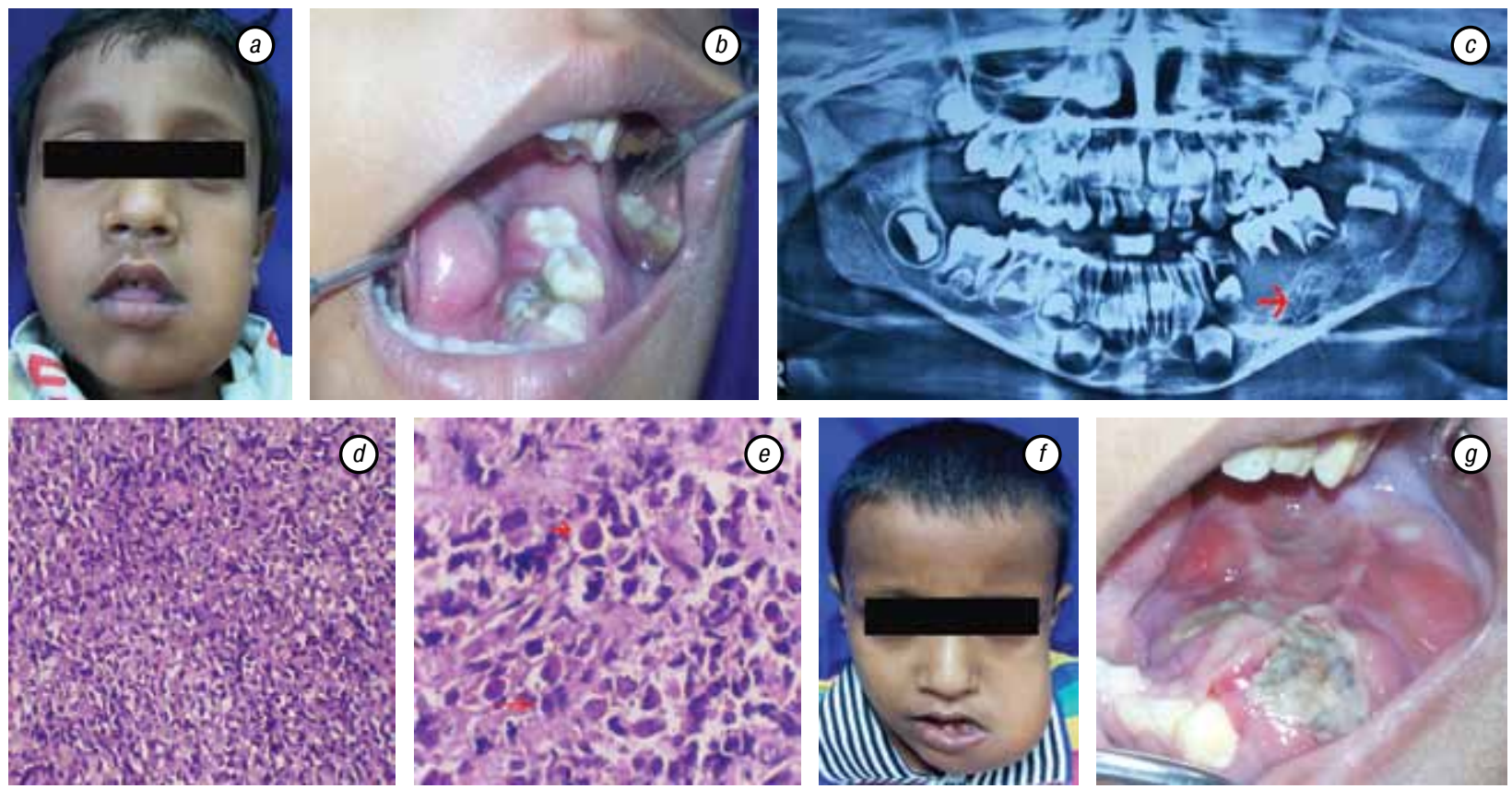

Fig. 2. Clinical, radiographic and histological findings of Case \#2: $a$ - extra oral photograph showing swelling over left angle of mandible that showed rapid expansion over a period of 1 week post incisional biopsy $(f) ; b$ - intraorally, swelling with expansion of buccal and lingual cortices and ulcer over the linguo-occlusal surface covered by grayish pseudomembrane was observed at first visit; $c$ - orthopantogram showing ill defined radiolucent lesion involving left posterior mandible causing resorption of molar roots (note the sunburst pattern at the periphery); $d$ - microphotograph with pleomorphic round to spindled tumor cells ( $\mathrm{H} \& \mathrm{E}, \times 100)$; $e$ - microphotograph showing immature tumor cells with varying degree of pleomorphism and mitotic activity (H \& E, $\times 1000) ; f-1$ week post biopsy, a massive increase in swelling; $g-1$ week post biopsy, the lesion showing massive expansion with an irregular, granular and necrotic appearance 

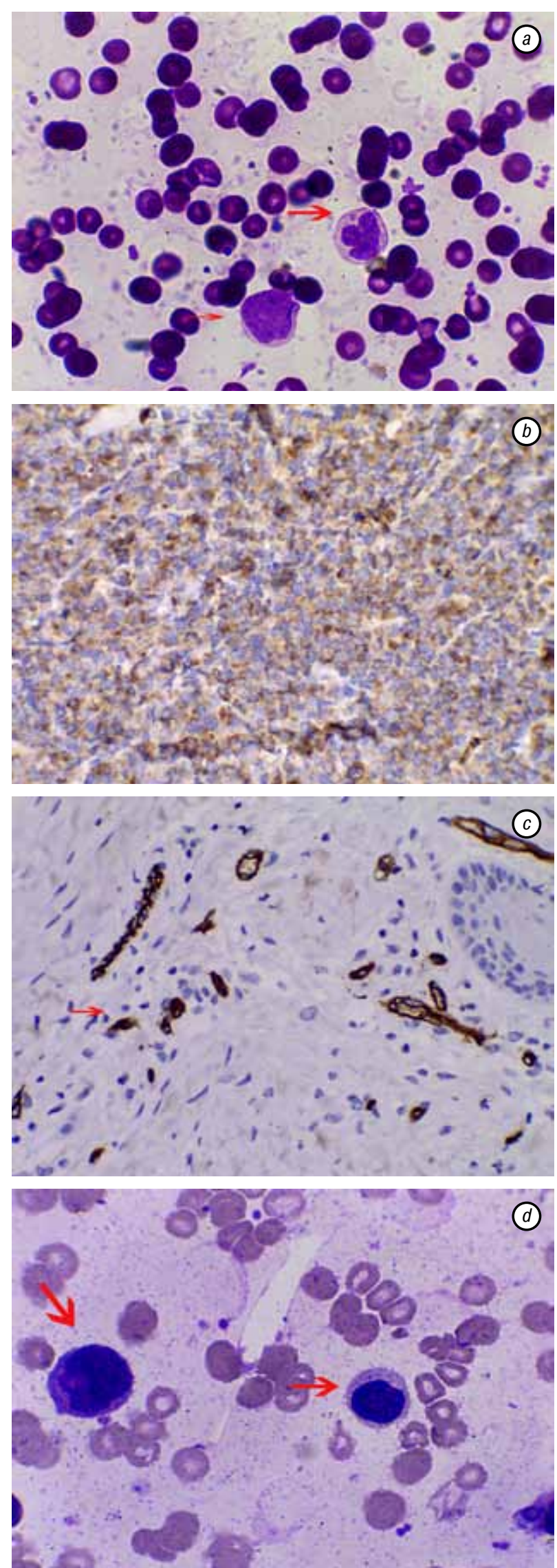

Fig. 3. Cytological and immunohistochemical findings of Case \#2: $a$ - peripheral smear showing presence of band forms and myeloblasts (Giemsa, $\times 100$ ); $b$ - diffuse positivity for MPO seen in all tumor cells $(\times 100) ; c-$ focal positivity for CD34 observed in some tumor cells $(\times 100), d-$ bone marrow aspirate showing numerous blast cells (Giemsa, $\times 100$ ) and a periosteal reaction giving a sunburst appearance (Fig. 2, c). Other than decreased hemoglobin level of $10.5 \mathrm{gm} / \mathrm{dl}$, all other hematological parameters were within normal limits.

An incisional biopsy was subsequently performed along with extraction of the mobile teeth. Biopsy showed diffuse infiltration of predominantly round cells effacing the tissue architecture. The cells had sparse to moderate eosinophilic cytoplasm with prominent nuclei. Abundant mitotic figures were seen with mitoses ranging from 5-6 per high power field (Fig. 2, d,e).

Based on $\mathrm{H}$ \& E sections, Ewing's sarcoma, embryonic rhabdomyosarcoma, and neuroblastoma were included in the differential diagnosis. The tumor cells were negative for vimentin, desmin, CD99, CD45 and NSE. In the mean time, the patient reported with a massive increase in swelling (7 days post biopsy) (Fig. 2, $f, g$ ).

A peripheral smear was repeated and numerous immature blasts including myeloblasts, and band forms were observed (Fig. 3, a). Immunohistochemistry was then done using anti-MPO (Fig. $3, b)$ and anti-CD34 (Fig. 3, c). The tumor cells were diffusely positive for MPO and focally positive for CD34. The lesion was thus diagnosed as MS. Subsequently, bone marrow biopsy was performed that showed marrow involvement with atypical cells with high nuclear-tocytoplasmic ratio, focal nuclear convolutions and moderate to scant cytoplasm (Fig. 3, d). These atypical cells constituted more than $50 \%$ of marrow population. Strong MPO activity was also noticed in these atypical cells. MS presenting with AML was the final diagnosis. The left deciduous second molar was decalcified and showed dense diffuse infiltration by tumor cells completely obliterating the pulpal architecture (Fig. 4).

Patient underwent chemotherapy with cytarabine followed by successful lesion regression. He is currently in remission, one year post diagnosis.

A thorough search of world literature revealed 77 cases of intraoral MS, of which 44 lesions either preceded or presented concomitantly with leukemia. Diagnostic criteria used for these lesions (MS presenting with or preceding leukemia) have been compiled in Table 1 [1-46].

\section{DISCUSSION}

The diagnosis of MS can be a clinical challenge when there is no antecedent myeloid neoplasm. It has been reported that up to $27 \%$ cases present de novo and there may be a lag of up to 10 months between first presentation and bone marrow involvement $[45$, 46]. A high degree of clinical suspicion thus becomes mandatory in order to establish diagnosis. In a study of $26 \mathrm{MS}$ cases by Menasce etal. [47], 14 were initially misdiagnosed, all 14 being without prior history of leukemia or myeloproliferative disorders. Further Byrd et al. [48] in their study found that up to $46 \%$ of published isolated cases were misdiagnosed, commonly as large cell lymphomas. The differential diagnosis of MS is quite large and clinical features such as age 

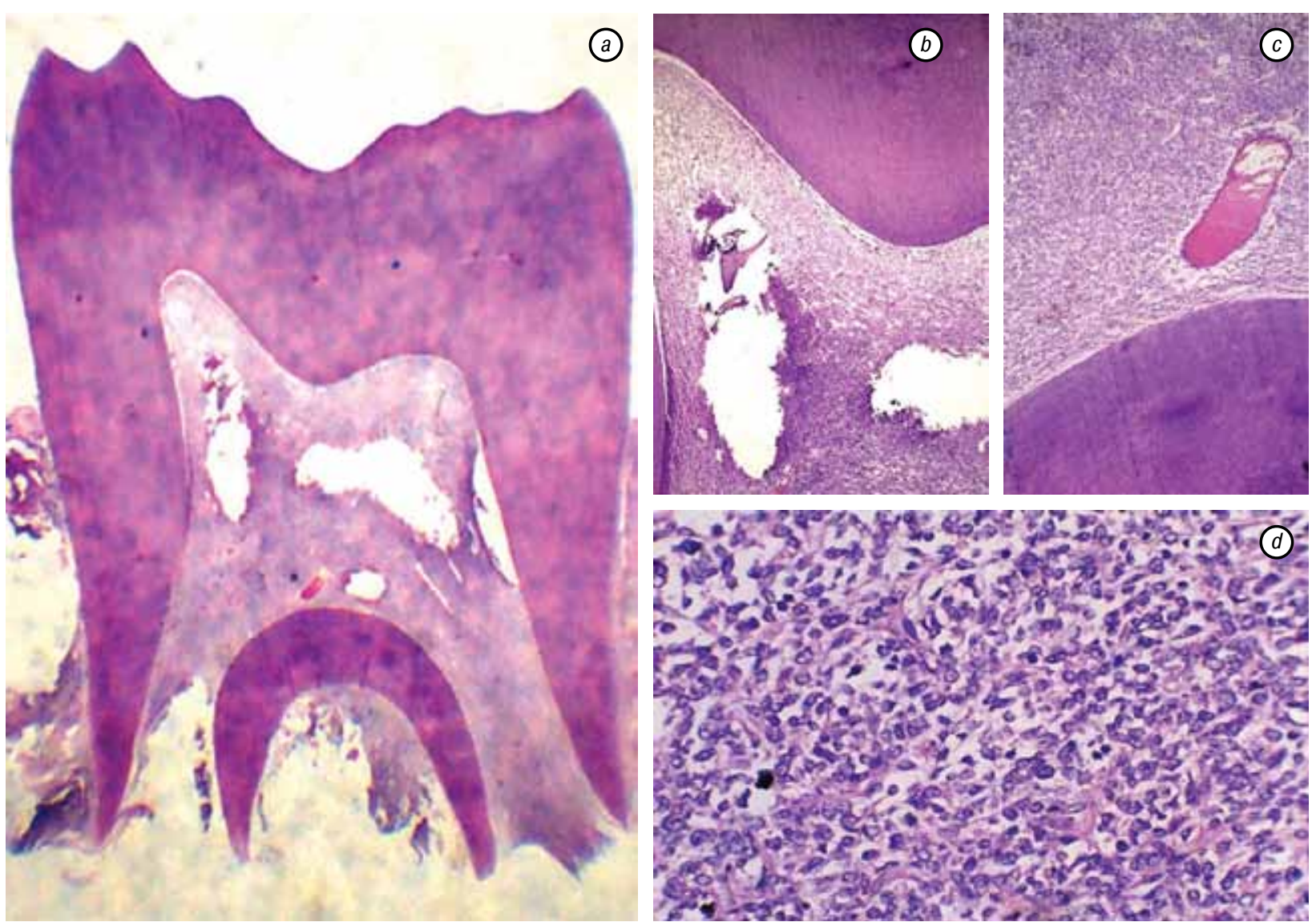

Fig. 4. Decalcified section of left permanent first molar (Case \#2) showing diffuse infiltration and effacement of pulpal architecture by tumor cells: $a-\mathrm{H} \& \mathrm{E}, \times 20 ; b-\mathrm{H} \& \mathrm{E}, \times 40 ; c-\mathrm{H} \& \mathrm{E}, \times 40 ; d-\mathrm{H} \& \mathrm{E}, \times 400$

along with presence of a preexisting or concurrent myeloid neoplasm must be factored in.

The pathogenesis of MS has been attributed to an aberrant homing signal for the leukemic blast cells rather than their localization within the bone marrow [1]. Studies have shown that this homing and retention of the blasts may be mediated by different chemokine/chemokine receptor activations and the invasive potential of the cells is due to interactions between MMPs and integrins [49-51].

The clinical features of oral MS can be extremely variable and nonspecific. Patients may present with swelling, sore throat, purulent discharge, jaw pain, mobile teeth, sinus pain, tonsillar enlargement and lymphadenopathy amongst others [41]. MS has been reported at almost all intraoral sites with the mandible accounting for the maximum number of cases (35\%). The most common site for extraoral MS is the skin (leukemia cutis) where it presents as multiple papules, plaques and nodules [34]. Radiographically, intraosseous oral lesions vary from innocuous appearing periapical granulomas/ abscesses and superficial bony erosion to massive destructive expansile lesions involving large areas of the jaw $[1,9,11,52]$. Periosteal reactions around the lesion and sinus haziness are some of the other reported findings.

Morphologically, MS classically presents as a tumor composed of immature cells namely myeloblasts, monoblasts and rarely promyelocytes that partially or completely efface the overall architecture of the tissue involved. The cells show scant cytoplasm with multilobed round to oval nuclei, fine or dusty nuclear chromatin and one or two small basophilic nucleoli [53, 54]. MS were historically divided into granulocytic sarcoma and monocytic sarcoma. Pileri et al. [45] in 2007 further classified GS into three variants as per the morphological type. Blastic variant shows predominance of myeloblasts with little evidence of maturation and no cytoplasmic granules, immature type (intermediate grade) consists of myeloblasts, promyelocytes and eosinophilic myelocytes and differentiated or mature type shows promyelocytes, and more mature cells with abundance of eosinophils. According to this classification, Case \#1 belongs to the differentiated type and Case \#2 to the blastic type. However, the cytomorphologic classification has no bearing on prognosis and is hence clinically irrelevant $[47,55]$.

With increase in cytogenetic and molecular understanding of these tumors, the abovementioned morphological distinctions seem less relevant. At the same time, sufficient knowledge regarding the immunohistochemical makeup of the various subtypes may prove critical in establishing diagnosis. A number of studies describing the immunophenotype of MS have shown that the tumor can show features of any myeloid lineage and often may show multiple lineage expression in the same tumor $[34,53]$. A number of enzyme cytochemical stains such as myeloperoxidase, sudan black $B$, chloracetate 
Table 1. Diagnostic criteria used for intraoral MS preceding or presenting with leukemia

\begin{tabular}{|c|c|c|c|c|c|c|c|c|}
\hline No. & Authors/Reference & Year & $\begin{array}{l}\text { Age/ } \\
\text { Sex }\end{array}$ & Location & $\begin{array}{l}\text { Type of ma- } \\
\text { lignancy }\end{array}$ & Diagnosis based on: & $\begin{array}{l}\text { Marrow sta- } \\
\text { tus at the } \\
\text { time of di- } \\
\text { agnosis }\end{array}$ & $\begin{array}{l}\text { Time to leukaemia } \\
\text { diagnosis }\end{array}$ \\
\hline 1 & Wiernick et al. [4] & 1970 & $35 / F$ & Cheek & $\overline{A M L}$ & $H \& E$ & Uninvolved & 10 months after MS \\
\hline 2 & Brooks et al. [5] & 1974 & 8/M & Maxillary sinus & AML & $H \& E$ & Uninvolved & 4 years \\
\hline 3 & Hansen et al. [6] & 1982 & $83 / F$ & Maxilla & AML & NA & Uninvolved & 3 months after MS \\
\hline 4 & Conran et al. [7] & 1982 & $2 / F$ & Mandible & None & $\begin{array}{l}\mathrm{H} \& \mathrm{E} \\
\text { Ultrastructural analysis }\end{array}$ & Uninvolved & DF \\
\hline 5 & Takagi et al. [8] & 1983 & $25 / \mathrm{F}$ & Mandible & AML & $\mathrm{IHC}$ - MPO & Uninvolved & 1 year 6 mos after MS \\
\hline 6 & Reichart et al. [9] & 1984 & $35 / F$ & Mandible & $\begin{array}{l}\text { AML, pro- } \\
\text { myelocytic }\end{array}$ & CS - chloracetate esterase & Uninvolved & 3 months after MS \\
\hline 7 & Castella et al. [10] & 1984 & $89 / F$ & Hard palate & None & $\begin{array}{l}\text { CS - chloracetate esterase } \\
\text { Ultrastuctural analysis }\end{array}$ & DF & $\begin{array}{l}\text { Died of unrelated } \\
\text { cause }\end{array}$ \\
\hline 8 & Timmis et al. [11] & 1986 & $52 / \mathrm{M}$ & Mandible & LL & $\begin{array}{l}\text { CS - Sudan black, chloracetate esterase } \\
\text { IHC - HLA, Leu-M3 } \\
\text { Ultrastructural analysis }\end{array}$ & Involved & Diagnosed with MS \\
\hline 9 & Ficarra et al. [12] & 1987 & $67 / F$ & Hard palate & $\mathrm{AML}$ & CS - chloracetate esterase & & 1 year 3 mos after MS \\
\hline 10 & $\begin{array}{l}\text { De Vicente } \\
\text { Rodriquez et al. [13] }\end{array}$ & 1990 & $56 / \mathrm{M}$ & Left mandible & AML & $\begin{array}{l}\text { CS - chloracetate esterase } \\
\text { IHC - lysozyme }\end{array}$ & Involved & Diagnosed with MS \\
\hline 11 & $\begin{array}{l}\text { Eisenberg et al. } \\
{[14]}\end{array}$ & 1991 & $33 / \mathrm{M}$ & Multiple sites & None & $\begin{array}{l}\text { CS - Sudan black, MPO, a-naphthyl butyrate } \\
\text { esterase }\end{array}$ & Uninvolved & DF \\
\hline 12 & Stack et al. [15] & 1994 & 70/M & Mandible & $\mathrm{CML}$ & $\begin{array}{l}\text { CS - chloroacetate esterase; IHC - antilyso- } \\
\text { zomal peroxidase }\end{array}$ & Involved & Diagnosed with MS \\
\hline 13 & Roth et al. [16] & 1995 & $47 / \mathrm{M}$ & Gingiva & AML & NA & NA & NA \\
\hline 14 & Lynch et al. [17] & 1998 & $86 / F$ & Maxillary gingiva & AML & $\mathrm{IHC}-\mathrm{MPO}$ & Uninvolved & 2 years 5 mos after MS \\
\hline 15 & Tong et al. [18 ] & 2000 & $76 / F$ & Maxillary gingiva & AML & $\mathrm{IHC}-\mathrm{MPO}$ & Uninvolved & 7 months \\
\hline 16 & Amin et al. [19] & 2002 & $58 / \mathrm{M}$ & Hard palate & AML & $\begin{array}{l}\text { IHC - CD34 (weak) } \\
\text { FC - HLA-DR, CD11c, CD13, CD15, CD34, TdT } \\
\text { CG - trisomy } 13(47, \mathrm{XY},+13)\end{array}$ & Involved & Diagnosed with MS \\
\hline 17 & Jordan et al. [20] & 2002 & $62 / F$ & Mandible & AML & $\begin{array}{l}\text { CS - chloracetate esterase } \\
\text { IHC - CD43, MPO, CD15 } \\
\text { CG - normal }\end{array}$ & Uninvolved & 6 weeks \\
\hline 18 & Antmen et al. [21] & 2003 & $12 / F$ & Gingiva & AML & IHC - MPO, lyso & Uninvolved & Few weeks after MS \\
\hline 19 & Stoopler et al. [22] & 2004 & $50 / \mathrm{M}$ & Multiple sites & AML & IHC - LCA, CD43, CD34 (rare) & Involved & Diagnosed with MS \\
\hline 20 & Colella et al. [23] & 2005 & $62 / F$ & Maxillary gingiva & AML & IHC - MPO, lysozyme, CD45, CD68 & Uninvolved & Few weeks after MS \\
\hline 21 & $\begin{array}{l}\text { Koudstaal } \\
\text { et al. [24] }\end{array}$ & 2006 & $36 / \mathrm{M}$ & Hard palate & AML & $\begin{array}{l}\text { IHC - CD45, CD43, HLA-DR, CD4 (weak) } \\
\text { FC - CD117, CD56, CD13, HLA-DR, CD45, } \\
\text { CD33 (weak) } \\
\text { CG - abnormal }\end{array}$ & Uninvolved & 2 years \\
\hline 22 & Goteri et al. [25] & 2006 & $84 / F$ & Hard palate & None & IHC - CD45, CD43, CD34, MP0, CD68 & Uninvolved & DF \\
\hline 23 & Yinjun et al. [26] & 2006 & $44 / F$ & Gingiva & None & $\begin{array}{l}\mathrm{IHC}-\mathrm{MPO}, \mathrm{CD} 68 \\
\mathrm{CG}-\text { trisomy } 21\end{array}$ & Uninvolved & DF \\
\hline 24 & Yoon et al. [27] & 2006 & $63 / \mathrm{M}$ & Gingiva & AML & $\mathrm{IHC}-\mathrm{CD} 117, \mathrm{MPO}$ & Involved & Diagnosed with MS \\
\hline 25 & $\begin{array}{l}\text { Matsushita } \\
\text { et al. [28] }\end{array}$ & 2007 & $50 / \mathrm{M}$ & Maxillary gingiva & AML & $\mathrm{IHC}-\mathrm{MPO}, \mathrm{CD} 43$ & Involved & Diagnosed with MS \\
\hline 26 & $\begin{array}{l}\text { Mohmedbhai } \\
\text { et al. [29] }\end{array}$ & 2008 & $45 / M$ & Tongue & AML & $\begin{array}{l}\text { IHC - CD45, MPO, CD68 } \\
\text { FC - MPO, CD33, CD117 } \\
\text { CG - t(15;17) (q22;q12) }\end{array}$ & Involved & Diagnosed with MS \\
\hline 27 & Kim et al. [30] & 2009 & $4 / F$ & Mandible & AML & $\begin{array}{l}\text { IHC - MPO, CD34, CD43, CD79a, } \\
\text { FC - CD13, CD33, CD38, CD117, HLA-DR, MPO }\end{array}$ & Involved & Diagnosed with MS \\
\hline 28 & Lu et al. [31] & 2009 & $63 / F$ & Maxillary gingiva & AML & $\mathrm{IHC}$ - MPO, CD34, CD3 (rare), CD20 & Involved & Diagnosed with MS \\
\hline 29 & Lu et al. [31] & 2009 & $39 / F$ & Maxilla & None & $\mathrm{IHC}-\mathrm{MPO}, \mathrm{CD} 34$ & Uninvolved & DF \\
\hline 30 & $\begin{array}{l}\text { Papamanthos } \\
\text { et al. [32] }\end{array}$ & 2010 & $70 / \mathrm{F}$ & Mandible & AML & IHC - CD43, lysozyme, MPO & Involved & Diagnosed with MS \\
\hline 31 & Qiu et al. [33] & 2010 & $16 / F$ & Condyle & AML & NR & Involved & Diagnosed with MS \\
\hline 32 & Klco et al. [34] & 2011 & $39 / \mathrm{M}$ & Maxillary gingiva & AML & $\mathrm{IHC}-\mathrm{M}$ & Uninvolved & \\
\hline 33 & Colović et al. [35] & 2011 & $55 / F$ & Mandible & None (HIV) & $\begin{array}{l}\text { IHC - CD117, CD45, CD68, lysozyme, } \\
\text { CD13 (weak) }\end{array}$ & Uninvolved & $\begin{array}{l}\text { Dead at } 8 \text { months } \\
\text { (HIV related sepsis) }\end{array}$ \\
\hline 34 & Seema et al. [36] & 2011 & $5 / \mathrm{M}$ & Mandible & AML & IHC - MPO, TdT & Involved & Diagnosed with MS \\
\hline 35 & Mei et al. [37] & 2011 & $56 / \mathrm{M}$ & Multiple & None & IHC - CD34, CD45, CD56, CD117, MP0 & Uninvolved & DF \\
\hline 36 & $\begin{array}{l}\text { Yamashita et al. } \\
\text { [38] }\end{array}$ & 2012 & 1/M & Mandible & AML & $\begin{array}{l}\mathrm{IHC}-\mathrm{CD} 45 \\
\mathrm{FC}-\mathrm{CD} 33, \mathrm{CD} 65, \mathrm{MPO}\end{array}$ & Involved & Diagnosed with MS \\
\hline 37 & Kurdoğlu et al. [39] & 2013 & $29 / \mathrm{F}$ & Gingiva & AML & $\mathrm{IHC}-\mathrm{CD} 117, \mathrm{MPO}$ & NR & NR \\
\hline 38 & $\begin{array}{l}\text { Guastafierro } \\
\text { et al. [40] }\end{array}$ & 2013 & $56 / \mathrm{F}$ & Maxillary gingiva & $\begin{array}{l}\text { None (pleu- } \\
\text { ral effusion) }\end{array}$ & IHC - CD45, CD68, lysozyme, MP0 & Uninvolved & $\begin{array}{l}\text { Died due to other } \\
\text { causes }\end{array}$ \\
\hline 39 & Zhou et al. [41] & 2013 & $77 / \mathrm{F}$ & Tongue & MDS & $\begin{array}{l}\text { CS - chloracetate esterase } \\
\text { IHC - CD4, CD1c, CD33, CD43, CD68, CD117, } \\
\text { CD163, MP0, lysozyme } \\
\text { CG }-47, X X,+8[20]\end{array}$ & Involved & Diagnosed with MS \\
\hline 40 & Zhou et al. [41] & 2013 & $55 / \mathrm{M}$ & Mandible & $\mathrm{CML}$ & $\begin{array}{l}\text { IHC - MPO, CD43 } \\
C G-46, X Y, t(9 ; 22)(q 34 ; q 11)[20]\end{array}$ & Involved & Diagnosed with MS \\
\hline 41 & Zhou et al. [41] & 2013 & $47 / F$ & Tonsil & AML & $\begin{array}{l}\text { IHC - CD4, CD11c, CD33, CD43, CD45, CD68, } \\
\text { CD117, MP0, lysozyme, CD163 } \\
\text { CG - normal }\end{array}$ & Involved & Diagnosed with MS \\
\hline 42 & Sharma et al. [42] & 2014 & $9 / \mathrm{M}$ & Maxillary sinus & DF & $\mathrm{IHC}-\mathrm{CD}$ & Uninvolved & DF \\
\hline 43 & Ponnam et al. [43] & 2014 & $45 / F$ & Mandible & NA & IHC - CD45, CD68, CD117, MP0 & NR & NR \\
\hline 44 & Moshref et al. [44] & 2014 & $45 / M$ & Multiple sites & $\mathrm{DF}(\mathrm{MI})$ & IHC - CD45, C-Kit & Uninvolved & $\begin{array}{c}\text { Died due to Ml after } \\
10 \text { months }\end{array}$ \\
\hline
\end{tabular}




\begin{tabular}{|c|c|c|c|c|c|c|c|}
\hline No. Authors/Reference & Year & $\begin{array}{l}\text { Age/ } \\
\text { Sex }\end{array}$ & Location & $\begin{array}{l}\text { Type of ma- } \\
\text { lignancy }\end{array}$ & Diagnosis based on: & $\begin{array}{l}\text { Marrow sta- } \\
\text { tus at the } \\
\text { time of di- } \\
\text { agnosis }\end{array}$ & $\begin{array}{c}\text { Time to leukaemia } \\
\text { diagnosis }\end{array}$ \\
\hline $\begin{array}{ll}45 & \text { Present case } \\
46 & \text { Present case } \\
\end{array}$ & $\begin{array}{l}2016 \\
2016 \\
\end{array}$ & $\begin{array}{l}28 / \mathrm{M} \\
5 / \mathrm{M} \\
\end{array}$ & $\begin{array}{l}\text { Left mandible } \\
\text { Left mandible }\end{array}$ & $\begin{array}{c}\mathrm{DF} \\
\mathrm{AML} \\
\end{array}$ & $\begin{array}{l}\mathrm{IHC}-\mathrm{CD} 45, \mathrm{MPO} \\
\mathrm{IHC}-\mathrm{MPO}, \mathrm{CD} 34\end{array}$ & $\begin{array}{l}\text { Uninvolved } \\
\text { Involved }\end{array}$ & $\begin{array}{c}\mathrm{DF} \\
\text { Diagnosed with MS }\end{array}$ \\
\hline
\end{tabular}

Table 2. Immunohistochemical differential diagnosis of MS

\begin{tabular}{|c|c|c|c|c|c|c|c|c|c|c|}
\hline \multirow{2}{*}{ Antibody } & \multirow{2}{*}{ Specificity } & \multicolumn{2}{|l|}{ MS } & \multicolumn{2}{|c|}{$\begin{array}{c}\text { Non-Hodg- } \\
\text { kin's lymphoma }\end{array}$} & \multirow{2}{*}{$\begin{array}{c}\text { Ewing } \\
\text { sarco- } \\
\text { ma }\end{array}$} & \multirow{2}{*}{$\begin{array}{l}\text { Epithe- } \\
\text { loid sar- } \\
\text { coma }\end{array}$} & \multirow{2}{*}{$\begin{array}{l}\text { Poorly dif- } \\
\text { ferentiated } \\
\text { carcinoma }\end{array}$} & \multirow{2}{*}{$\begin{array}{l}\text { Melano- } \\
\text { ma }\end{array}$} & \multirow{2}{*}{$\begin{array}{c}\text { Langerhans } \\
\text { cell histio- } \\
\text { cytosis }\end{array}$} \\
\hline & & $\begin{array}{c}\begin{array}{c}\text { Nonmono- } \\
\text { cytic }\end{array} \\
\end{array}$ & $\begin{array}{l}\text { Mono- } \\
\text { cytic }\end{array}$ & B cell & T cell & & & & & \\
\hline CD43 & T cells, myeloid cells, subset of B cells, T\& B cell lymphomas & +++ & +++ & ++ & $\overline{+++}$ & - & - & - & - & - \\
\hline Lysozyme & Myeloid \& monocyte/macrophage lineage cells & +++ & +++ & - & - & - & - & - & - & - \\
\hline MPO & Myeloid lineage cells & +++ & - & - & - & - & - & - & - & - \\
\hline CD68 & Monocyte/macrophage lineage cells & ++ & ++ & - & - & - & - & - & - & - \\
\hline CD34 & $\begin{array}{l}\text { Vascular progenitor cells, endothelial cells, interstitial } \\
\text { cells of cajal, leukemic blasts, some soft tissue tumors }\end{array}$ & ++ & - & - & - & - & ++ & - & - & - \\
\hline CD45 & $\begin{array}{l}\text { T \& B lymphocytes, monocytes, macrophages, mast } \\
\text { cells \& weakly on granulocytes }\end{array}$ & + & + & +++ & +++ & - & - & - & - & - \\
\hline CD117 & $\begin{array}{l}\text { Interstitial cells of cajal, germ cells, bone marrow stem } \\
\text { cells, breast epithelium, melanocytes \& mast cells }\end{array}$ & ++ & - & - & - & - & - & - & - & - \\
\hline CD33 & Cells of myeloid lineage, some lymphoid cells & ++ & + & - & - & - & - & - & - & - \\
\hline CD3 & T lymphocytes & + & - & - & +++ & - & - & - & - & - \\
\hline CD20 & B lymphocytes & - & - & +++ & - & - & - & - & - & - \\
\hline CD99 & $\begin{array}{l}\text { Ewing sarcoma, primitive neuroectodermal tumor, } \\
\text { peripheral neuroepithelioma }\end{array}$ & + & - & + & ++ & +++ & - & - & - & - \\
\hline Others & & & & & CD79a & $\begin{array}{l}\text { FLI1 } \\
\text { S100 } \\
\text { NSE }\end{array}$ & $\begin{array}{c}\text { CK } \\
\text { INI-1 } \\
\text { Vimentin } \\
\text { EMA }\end{array}$ & $\begin{array}{l}\text { High \& low } \\
\text { weight CK }\end{array}$ & $\begin{array}{c}\text { HMB } 45 \\
\text { Melan A } \\
\text { S } 100\end{array}$ & $\begin{array}{l}\text { CD1a } \\
\text { S100 }\end{array}$ \\
\hline
\end{tabular}

Note: +++ strongly positive, ++ frequently positive, + rarely positive, - negative.

esterase, a-naphthyl acetate esterase and a-naphthyl butyrate esterase have also been described.

Although the immunohistochemical panel for MS is well established, diagnosis may still be difficult for tumors presenting in the absence of a known primary. CD43 and lysozyme having a high sensitivity but low specificity are the most commonly used markers. Other routinely used markers include MPO, CD68 (KP-1 clone), CD34, CD45, CD117 and CD33. However, tumors of purely monocytic origin are negative for CD34, CD117 and MPO and positive for CD68, CD43, and CD33 [34, 53, 56].

A guide to the immunohistochemical differential diagnosis of MS is given in Table 2.

The most common differential diagnosis for MS in the adult population is non-Hodgkin's lymphoma ( $T$ \& B cell type) [47]. It is especially true for $T$ cell neoplasms as MS may express many markers of T cell differentiation namely, CD2, CD4, CD7, CD43, and CD45. Immature MS with no evidence of differentiation is usually misdiagnosed as diffuse large $B$ cell lymphoma which has thick nuclear membrane and basophilic nucleoli, unlike myeloblasts or monoblasts, which have thin nuclear membranes and pinpoint nucleoli [57]. The use of a comprehensive immunohistochemical panel including lysozyme, MPO and CD68 thus becomes mandatory when dealing with such lesions. Other neoplasms that need to be differentiated are poorly differentiated carcinomas, melanomas and epitheloid sarcomas.

In pediatric population, differentiating MS from small round blue cell tumors such as Ewing's, primitive neuroectodermal tumors, neuroblastoma and alveolar rhabdomyosarcoma may become challenging. As seen in the case reported here, the radiographic appearance of a destructive radiolucent lesion surrounded by periosteal reaction giving a sun burst appearance may also favor a diagnosis of Ewing's sarcoma. The expression of CD99 by a large number of nonmonocytic MS further impedes diagnosis. However, positive expression of CD43, lysozyme and MPO swings the diagnosis in favor of MS. While dealing with children and young adults, it is prudent to exclude Langerhans cell histiocytosis from the differential diagnosis. The grooved coffee bean like nuclei of Langerhan's cells and abundance of eosinophils in the background is often seen in the monocytic MS [58].

Apart from immunohistochemistry, flow cytometric analysis using CD13, CD33, CD117 and MPO for non-monoblastic MS and CD14, CD163, and CD11C in monoblastic MS is well established when fresh tissue is available [1]. Cytogenetic abnormalities have been reported in approximately $50 \%$ of the MS cases and mirror the cytogenetic changes associated with AML. Interestingly, de novo cases of MS may lack these abnormalities. Pileri et al. [45] through FISH demonstrated trisomy 8 and monosomy 7 as the most common abnormalities. Trisomy 8 and inv (16) as determined by conventional cytogenetics was reported by Alexeiv et al. [59]. Pediatric patients having $t(8 ; 21)$ (q22;22) karyotypic abnormality have been shown to have a predilection for head and neck involvement including the orbit and CNS [60].

Molecular abnormalities in MS are not very well established. Mutations in nucleophosmin (NPM) 1 and 
its resultant aberrant cytoplamic expression have been reported in approximately $15 \%$ of MS patients [61]. The prevalence of Fms like tyrosine kinase-3 (FLT3) mutations has been reported in a small subset of MS cases [62]. The significance of these mutations on the prognosis of MS patients is yet unknown.

With respect to available therapeutic options, there is a lack of consensus on treatment of MS with the recommended treatment regimen being conventional AML type chemotherapeutic protocols [1]. The role of radiotherapy in addition to chemotherapy is not well established with many studies showing no additional benefit $[63,64]$. Other therapeutic modalities include hematopoietic stem cell transplantation and targeted therapy [1]. The prognosis of patients with MS is usually poor with slightly better outcomes when compared to primary or relapsed AML without extramedullary involvement. MS accompanying chronic myeloid leukemia or myelodysplastic syndrome is said to have a worse clinical outcome when compared to MS with AML.

To conclude, intraoral MS is a rare tumor with poor clinical outcome. It has protean clinical manifestations and histological overlap with numerous tumors making it a diagnostic challenge for clinicians and pathologists alike. When evaluating a tumor of unknown etiology, it is wise to maintain a high degree of suspicion especially if common antibody panels are negative for epithelial, mesenchymal or lymphoid markers. Apart from immunohistochemistry, use of ancillary techniques such as cytogenetics and bone marrow examination may assist in diagnosing. Arriving at prompt accurate diagnosis facilitates timely and effective therapeutic intervention thus improving patient outcomes.

\section{Conflict of interest: Nil.}

\section{REFERENCES}

1. Avni B, Koren-Michowitz M. Myeloid sarcoma: current approach and therapeutic options. Ther Adv Hematol 2011; 2: 309-16.

2. Swerdlow SH, Campo E, Harris NL, et al. WHO Classification of tumours of haematopoietic and lymphoid tissues. Lyon, France: IARC Press, 2008: 140-1.

3. Cunningham I. Extramedullary sites of leukemia relapse after transplant. Leuk Lymphoma 2006; 47: 2517-26.

4. Wiernik PH, Serpick AA. Granulocytic sarcoma (chloroma). Blood 1970; 35: 361-9.

5. Brooks HW, Evans AE, Glass RM, Pang EM. Chloromas of the head and neck in childhood. The initial manifestation of myeloid leukemia in three patients. Arch Otolaryngol 1974; 100: 306-8.

6. Hansen LS, Merrell PW, Bainton DF, Taylor KL. Granulocytic sarcoma: an aleukemic oral presentation. CDA J 1982; 10: $41-6$.

7. Conran MJ, Keohane C, Kearney PJ. Chloroma of the mandible: a problem of diagnosis and management. Acta Paediatr Scand 1982; 71: 1041-3.

8. Takagi M, Ishikawa G, Kamiyama R. Granulocytic sarcoma of the jaw. Bull Tokyo Med Dent Univ 1983; 30: 1-7.

9. Reichart PA, van-Roemeling R, Krech R. Mandibular myelosarcoma (chloroma): primary oral manifestation of promyelocytic leukemia. Oral Surg Oral Med Oral Pathol 1984; 58: 424-7.
10. Castella A, Davey FR, Elbadawi A, Gordon GB. Granulocytic sarcoma of the hard palate: report of the first case. Hum Pathol 1984; 15: 1190-2.

11. Timmis DP, Schwartz JG, Nishioka G, Tio F. Granulocytic sarcoma of the mandible. J Oral Maxillofac Surg 1986; 44: 814-8.

12. Ficarra G, Silverman S, Quivey JM, et al. Granulocytic sarcoma (chloroma) of the oral cavity: a case with aleukemic presentation. Oral Surg Oral Med Oral Pathol 1987; 63: 709-14.

13. De Vicente Rodriguez JC, Lopez Arranz JS, Fresno Forcelledo M. Isolated granulocytic sarcoma: report of a case in the oral cavity. J Oral Maxillofac Surg 1990; 48: 748-52.

14. Eisenberg E, Peters E, Krutchkoff DJ. Granulocytic sarcoma (chloroma) of the gingiva. J Oral Maxillofac Surg 1991; 49: 1346-50.

15. Stack BC, Ridley MB. Granulocytic sarcoma of the mandible. Otolaryngol Head Neck Surg 1994; 110: 591-4.

16. Roth MJ, Medeiros J, Elenitoba-Johnson $\mathrm{K}$, et al. Extramedullary myeloid cell tumors. An immunohistochemical study of 29 cases using routinely fixed and processed paraffin-embedded tissue sections. Arch Pathol Lab Med 1995; 119: 790-8.

17. Lynch DP, Conlon TO, Maxwell GR, Matinez F. Exophytic gingival mass in a geriartic patient. Oral Surg Oral Med Oral Pathol Oral Radiol Endod 1998; 85: 5-7.

18. Tong ACK, Lam KY. Granulocytic sarcoma presenting as an ulcerative mucogingival lesion: report of a case and review of the literature. J Oral Maxillofac Surg 2000; 58: 1055-8.

19. Amin KS, Ehsan A, McGuff HS, Albright SC. Minimally differentiated acute myelogenous leukemia (AML-M0) granulocytic sarcoma presenting in the oral cavity. Oral Oncol 2002; 38: 516-9.

20. Jordan RCK, Glenn L, Treseler PA, Regezi JA. Granulocytic sarcoma: case report with an unusual presentation and review of the literature. J Oral Maxillofac Surg 2002; 60: $1206-11$.

21. Antmen B, Haytac MC, Sasmaz I, et al. Granulocytic sarcoma of gingiva: an unusual case with aleukemic presentation. J Periodontol 2003; 74: 1514-9.

22. Stoopler ET, Pinto A, Alawi F, et al. Granulocytic sarcoma: an atypical presentation in the oral cavity. Spec Care Dentist 2004; 24: 65-9.

23. Colella G, Tirelli A, Capone R, et al. Myeloid sarcoma occurring in the maxillary gingiva: a case without leukemic manifestations. Int J Hematol 2005; 81: 138-41.

24. Koudstaal MJ, van der Wal $\mathrm{KGH}$, Lam $\mathrm{KH}$, et al. Granulocytic sarcoma (chloroma) of the oral cavity: Report of a case and literature review. Oral Oncology Extra 2006; 42: $70-7$.

25. Goteri G, Ascani G, Messi M, et al. Myeloid sarcoma of the maxillary bone. J Oral Pathol Med 2006; 35: 254-6.

26. Yinjun L, Jie J, Zhimei C. Granulocytic sarcoma of the gingiva with trisomy 21. Am J Hematol 2006; 81: 79-80.

27. Yoon AJ, Pulse C, Cohen LD, et al. Myeloid sarcoma occurring concurrently with drug-induced gingival enlargement. J Periodontol 2006; 77: 119-22.

28. Matsushita K, Abe T, Takeda Y, et al. Granulocytic sarcoma of the gingiva: two case reports. Quintessence Int 2007; 38: 817-20.

29. Mohamedbhai S, Pule M, Conn B, et al. Acute promyelocytic leukaemia presenting with a myeloid sarcoma of the tongue. Br J Haematol 2008; 141: 565.

30. Kim K, Velez I, Rubin D. A rare case of granulocytic sarcoma in the mandible of a 4-year-old child: a case report and review of the literature. J Oral Maxillofac Surg 2009; 67: 410-6. 
31. Lu DH, Chen F, Zhang QG, Guan DN. Granulocytic sarcoma of oral cavity: report of two cases. Hua Xi Kou Qiang Yi Xue Za Zhi 2009; 27: 110-2.

32. Papamanthos MK, Kolokotronis AE, Skulakis HE, et al. Acute myeloid leukaemia diagnosed by intra-oral myeloid sarcoma. A case report. Head Neck Pathol 2010; 4: 132-5.

33. Qiu YT, Yang C, Zhang XH. Primary granulocytic sarcoma of the mandibular condyle presenting with the characteristic green color. J Oral Maxillofac Surg 2010; 68: 2575-9.

34. Klco JM, Welch JS, Nguyen TT, et al. State of the art in myeloid sarcoma. Int J Lab Hematol 2011; 33: 555-65.

35. Colović N, Jurišić V, Terzić T, et al. Alveolar granulocytic sarcoma of the mandible in a patient with HIV. Onkologie 2011; 34: 55-8.

36. Seema S, Jay GR, Devi CS, et al. Granulocytic sarcoma of the oral cavity. Indian J Cancer 2011; 48: 378-80.

37. Mei KD, Lin YS, Chang SL. Myeloid sarcoma of the cheek and the maxillary sinus regions. J Chin Med Assoc 2013; 76: 235-8.

38. Yamashita $\mathrm{Y}$, Isomura $\mathrm{N}$, Hamasaki $\mathrm{Y}$, Goto $\mathrm{M}$. Case of pediatric acute promyelocytic leukemia presenting as extramedullary tumor of the mandible. Head Neck 2013; 35: E310-3.

39. Kurdoğlu B, Oztemel A, Barış E, Sengüven B. Primary oral myeloid sarcoma: report of a case. J Oral Maxillofac Pathol 2013; 17: 413-6.

40. Guastafierro S, Falcone U, Colella G. Gingival swelling and pleural effusion: non-leukemic myeloid sarcoma. Eur J Haematol 203; 9191: 4.

41. Zhou J, Bell D, Medeiros LJ. Myeloid sarcoma of the head and neck region. Arch Pathol Lab Med 2013; 137: $1560-8$.

42. Sharma A, Singh HP, Gupta AA, et al. Granulocytic sarcoma in non-leukaemic child involving maxillary sinus with long term follow up: a rare case report. Ann Maxillofac Surg 2014; 4: 90-5.

43. Ponnam SR, Srivastava G, Jampani N, Kamath VV. A fatal case of rapid gingival enlargement: Case report with brief review. J Oral Maxillofac Pathol 2014;18: 121-6.

44. Moshref M, Lotfi A, Mashhadi-Abbas F, Kargahi N. Granulocytic sarcoma (chloroma) presenting as multiple sites in oral cavity: report of a case. Iran J Cancer Prev 2014; 7: 53-7.

45. Pileri SA, Ascani S, Cox MC, et al. Myeloid sarcoma: clinico-pathologic, phenotypic and cytogenetic analysis of 92 adult patients. Leukemia 2007; 21: 340-50.

46. Neiman RS, Barcos M, Berard C, et al. Granulocytic sarcoma: a clinicopathologic study of 61 biopsied cases. Cancer 1981; 48: 1426-37.

47. Menasce LP, Banerjee SS, Beckett E, Harris M. Extra-medullary myeloid tumor (granulocytic sarcoma) is often misdiagnosed: a study of 26 cases. Histopathology 1999; 34: $391-8$.

48. Byrd JC, Weiss RB, Arthur DC, et al. Extramedullary leukaemia adversely affects hematologic complete remission rate and overall survival in patients with $\mathrm{t}(8 ; 21)(\mathrm{q} 22 ; \mathrm{q} 22)$ : results from cancer and leukaemia group B 8461. J Clin Oncol 1997; 15: 466-75.
49. Faaij CM, Willemze AJ, Revesz T, et al. Chemokine/ chemokine receptor interactions in extramedullary leukaemia of the skin in childhood AML: Differential roles for CCR2, CCR5, CXCR4 and CXCR7. Pediatr Blood Cancer 2010; 55: $344-8$.

50. Stefanidakis M, Karjalainen K, Jaalouk DE, et al. Role of leukemia cell invadosome in extramedullary infiltration. Blood 2009; 114: 3008-17.

51. Wang C, Chen Z, Li Z, Cen J. The essential roles of matrix metalloproteinase-2, membrane type 1 metalloproteinase and tissue inhibitor of metalloproteinase- 2 in the invasive capacity of acute monocytic leukemia SHI-1 cells. Leuk Res 2010; 34: 1083-90.

52. Fasanmade A, Pring M, Pawade J, et al. Rapidly progressing mass of anterior mandible following a dental extraction. Oral Surg Oral Med Oral Pathol Oral Radiol Endod 2010; 109: 330-4.

53. Seifert RP, Bulkeley W $3^{\text {rd }}$, Zhang L, et al. A practical approach to diagnose soft tissue myeloid sarcoma preceding or coinciding with acute myeloid leukemia. Ann Diagn Pathol 2014; 18: 253-60.

54. Markoc F, Bozdogan N, Yükrük FA, et al. Granulocytic sarcomas: difficulties in diagnosis. Tumori 2010; 96: 149-53.

55. Traweek ST, Arber DA, Rappaport H, Brynes RK. Extramedullary myeloid cell tumors. An immunohistochemical and morphologic study of 28 cases. Am J Surg Pathol 1993; 17: 1011-9.

56. Hagen PA, Singh C, Hart M, Blaes AH. Differential diagnosis of isolated myeloid sarcoma: a case report and review of the literature. Hematol Rep 2015; 7: 5709.

57. Lin P, Jones D, Dorfman DM, Medeiros LJ. Precursor B-cell lymphoblastic lymphoma:a predominantly extranodal tumor with low propensity for leukemic involvement. Am J Surg Pathol 2000; 24: 1480-90.

58. Haresh KP, Joshi N, Gupta C, et al. Granulocytic sarcoma masquerading as Ewing's sarcoma: a diagnostic dilemma. J Cancer Res Ther 2008; 4: 137-9.

59. Alexiev BA, Wang W, Ning Y, et al. Myeloid sarcomas: a histologic immunohistochemical and cytogenetic study. Diagn Pathol 2007; 2: 42.

60. Rege K, Powles R, Norton J, et al. An unusual presentation of acute myeloid leukaemia with pericardial and pleural effusions due to granulocyticsarcoma. Leuk Lymphoma 1993; 11: $305-7$.

61. Falini B, Lenze D, Hasserjian R, et al. Cytoplasmic mutated nucleophosmin (NPM) defines the molecular status of a significant fraction of myeloid sarcomas. Leukemia 2007; 21: $1566-70$.

62. Ansari-Lari MA, Yang CF, Tinawi-Aljundi R, et al. FLT3 mutations in myeloid sarcoma. Br J Haematol 2004; 126: $785-91$.

63. Lan TY, Lin DT, Tien HF, et al. Prognostic factors of treatment outcomes in patients with granulocytic sarcoma. Acta Haematol 2009; 122: 238-46.

64. Dusenbery KE, Howells WB, Arthur DC, et al. Extramedullary leukemia in children with newly diagnosed acute myeloid leukemia: a report from the Children's Cancer Group. J Pediatr Hematol Oncol 2003; 25: 760-8. 